\title{
DIE BINDING VAN DIE KONFESSIE
}

\section{Ons moet waak teen twee uiterstes}

Aan die een kant het die dogma as onversoenlike vyand die dogmatisme en aan die ander kant die antidogmatisme - dit hou enersyds die gevaar in van verabsolutering (oorskatting), en andersyds die gevaar van relativisme (onderskatting).

\section{i. Die gevaar van dogmatisme}

Dit beteken dat die kerklike dogma as gelykwaardig met die Skrif beskou word; die kerklike formulering van die waarheid word met die waarheid vereenselwig. Die dogma word absoluut gestel, feitlik word geen appèl op die Skrif toegelaat nie. In die Roomse Kerk het hierdie dwaling verwerkliking gevind daarin dat in die praktyk die belydenis op een lyn met die Skrif gestel word, anders (aldus Rome) raak die kerk verskeur en die skape verstrooi. Bavinck wys daarop dat selfs die Roomse Kerk die bewering nie aandurf dat die dogma wat die kerk bely identies is met die absolute, Goddelike waarheid self nie. Rome bely wel die onfeilbaarheid van die pous, maar hierdie pouslike onfeilbaarheid is van die apostoliese inspirasie wesenlik te onderskei; dit dek die sake maar nie die woorde nie en verhef die dogma dus nie in letterlike sin tot Woord van God nie. ${ }^{1}$

Tog kan ons dit nie anders sien as dat Rome die Bybel met sy konfessionalisme omhein nie. Ons moet in hierdie verband onthou dat die hele pouslike sisteem sy sluitsteen verkry het toe onder invloed van die Ultramontane en Jesuiete in 1870 die dogma van die onfeilbaarheid aangeneem is. Hierdie dogma hou die volgende in: dat die pous in sy amp as herder en leraar van alle Christene, kragtens sy allerhoogste outoriteit (wanneer hy dus ex cathedra spreek) 'n geloofs- en sedeleer verkondig wat in die hele kerk geld met bindende gesag; hierdie verkondiging - so word dit gesien geskied deur die goddelike bystand wat in die heilige Petrus aan die pous toegesê is; die pous is dan met die onfeilbaarheid werksaam, waarmee die Goddelike Verlosser gewil het dat sy kerk in die verkondiging van die geloofs- en sedeleer voorsien sou wees. Dit is die uiterste konsekwensie van die pouslike sisteem. Daar Rome die onfeilbaarheid van die kerk leer, laat hy die outoriteit van die dogma nie alleen op die Skrif rus nie, maar ook op die kerk, of liewer op die afkondiging deur die pous. Dit is ' $n$ leerstelsel wat deur dogmatisme gekenmerk word. Alle wesenlike onderskeid tussen openbaring en dogma word feitlik uitgewis.

Die pous is vir die Roomse Kerk die onfeilbare, sigbare opperhoof van die kerk. Hierdie kerkbeskouing lê ten grondslag aan die stelling: Roma locuta, causa finita est. Dit behels 'n absolute kerkgesag, soos ook blyk uit die Encycliek Inscrutabilis van Leo XIII (1878) wat spreek van die verhewe gesag van die kerk wat in die Naam van God die mensdom bestuur en die handhaafster en beskermster is van wettige gesag. Hierby word Skrif en tradisie as gelykwaardige openbaringsbronne aanvaar. Die Skrif kom te staan in die "ligweer- 
kaatsing" van die tradisie. Hierdeur word die Bybel ingeperk, kan die Woord van God as 't ware nie meer aan die woord kom nie en word dit gepers in die kader van die Roomse leersisteem.

\section{Openheid}

Berkouwer sinjaleer ' $n$ formeel soortgelyke bedreiging in die kring van die Protestantisme, en wel in die vorm van die sg. Konfessionalisme, waarin die openheid teenoor die nóu tot ons komende openbaringswoord dreig om verlore te gaan. ${ }^{2}$ Die belydenis ,vervang" dan die Skrif, soos die ekserp 'n studieboek vervang. Vir 'n eksamen kan 'n mens jou beperk tot jou eie ekserpte. Die studieboek het op 'n vroeër stadium sy funksie gehad. Ons het dan die boek vir ons praktiese gebruik gestabiliseer. Hiermee bedoel Berkouwer dat die Skrif sy "vormgewing" in die konfessie gevind het. Die Skrif lê agter ons. Voor ons lê die „ekserp". In hierdie beskouing het die Skrif tans nie meer vir ons lewende aktualiteit nie. Die Skrif mag in ons herinnering voortleef as eerbiedwaardige grootheid, ja, dit mag in ons Bybelondersoek nog 'n plek hê, maar die Bybel is nog net van belang om dit wat gevind is, dieper te fundeer en apologeties veilig te stel.

Tussen hierdie konfessionalisme en die Roomse visie bestaan daar ondanks alle verskil, 'n verrassende ooreenkoms, nl. dat die Skrif die ,agtergrond" word van die gebeure van die kerk. En dit is 'n baie gevaarlike versoeking vir die kerk. Wanneer ons - aldus Berkouwer - teenoor Rome die beskuldiging uitspreek dat die Skrif die ,agtergrond" geword het, dan het ons allermins rede om dit uit die hoogte te doen. Dan dink Berkouwer, verklaar hy, aan alle Protestante se sonde teenoor die magtige, soewereine Woord. Daar is vir elke gelowige 'n permanente bedreiging dat hy die verhouding tussen Skrif en kerk kan skeeftrek en die Skrif tot onwerksame agtergrond kan devalueer, en só oorbly in die eensaamheid van sy eie religieuse gedagtes, steriel en sonder seën. In hierdie verband word ons aan die woorde van die Roomse teoloog Brom herinner dat die Protestante ook besig is om die Bybel te verloor, en aan dié van dr. E. D. Kraan dat die vermindering van die persoonlike Bybellees die kraak van die balk beteken wat die val van die Westerse Christendom voorspel.

Wanneer die Skrif die „onwerksame agtergrond" geword het, tree in die kerk verstarde tradisionalisme met die status van 'n selfstandige mag (soos by Rome), versteende ortodoksisme en valse, dooie konserwatisme na vore.

\section{Hersiening}

Onder dogmatisme verstaan Polman nie net 'n sekere oorskatting van die dogma nie, maar dit is 'n oorskatting van so 'n aard dat dit die hele denklewe beheers. ${ }^{3}$ Van dogmatisme is daar sprake sodra hierdie dogma as 'n adekwate (volkome) uitdrukking van die waarheid beskou word; van hierdie dogma dus geen hoër beroep op die 
waarheid toegelaat word nie; die subjektiewe faktore wat tot die vasstel van 'n dogma meegewerk het, oor die hoof gesien en daarom hersiening van die dogma ontoelaatbaar geag word.

Die kerklike dogma omskrywe ons as die gelowige besinning oor die Skrifopenbaring, deur die kerk geformuleer en met gesag voorgedra om te glo. Dit blyk nou dat die dogmatisme hom in verskillende vorme kan openbaar. Dit is dogmatisme wanneer enige gelowige besinning oor die Skrifopenbaring identies verklaar word met die Skrifopenbaring self. Dit is dogmatisme wanneer die kerklike dogma as gelykwaardig met die Skrif beskou word. Dit is dogmatisme wanneer die kerklike formulering van die waarheid met die waarheid vereenselwig word. Daar word nie genoeg gereken met die relatiwiteit van die dogma nie - op een of ander manier word dit absoluut gemaak, feitlik geen appèl van die dogma op die Skrif word toegelaat nie.

\section{ii. Die gevaar van die Antidogmatisme}

Dit is die antipode van die dogmatisme. Sedert Schleiermacher het dit hom as 'n nog gevaarliker vyand van die dogma bewys as die dogmatisme. Dit kant hom of teen die besinningselement in die dogma, ò teen die gemeenskapselement, ò teen die historiese, of teen die gesagselement in die dogma, ò ook wel teen meer as een of sommer al die elemente tegelyk, en ondergaan die lot van alle subjektivisme. Teen die kerk en sy dogma kom die menslike hart telkens in opstand. Teenoor die verstarde dogmatisme kry ons hier 'n soepelheid en toeskietlikheid wat dikwels die waarheid totaal relativeer en tugteloosheid en losbandigheid tot gevolg het.

\section{Voorbeelde}

Ons gaan hier verwys na sekere strominge en standpunte wat, indien hulle nie bewustelik anti-dogmatisties is nie, tog die harmoniese dogmabeskouing uitsluit of ondermyn - die beskouing naamlik wat sowel die objektiewe as die subjektiewe in die dogma tot sy reg laat kom, die beskouing wat die relatiewe karakter van die dogma erken en tegelykertyd die waarheid van die dogma handhaaf.

Ons sou kón teruggaan na die tyd van die Reformasie. Dit is merkwaardig dat die Humanis, Desiderius Erasmus, koud gestaan het teenoor die konfessie, terwyl Martin Luther gehunker het na die vastigheid van die belydenis en 'n sondige verdraagsaamheid teenoor afwykende strominge as teken van karakterloosheid van die kerke beskou het.

Die Biblisistiese rigtings dwaal daarin dat hulle die belydenis as blote mensewoord verwerp, die historie misken, die leiding van die Heilige Gees wat Doctor ecclesiae is en die kerk in die waarheid van die Skrif gelei het om hierdie waarhede in die belydenis reg te repeteer, verloën en maak asof daar in die verlede nog nooit enige Geestesleiding in die waarheid was nie. Elke sekte het gedurig geroep: ons grond ons alleen op die Woord van God, en homself dan gedra asof die leerinhoud van die Heilige Skrif nog nooit vantevore 
onder leiding van die Heilige Gees ontdek en in sy dele nagesoek is nie, sodat daardie spesiale sekte dit nou vir die eerste keer in die loop van die eeue goed en deeglik aan die mense sou sê. So word vryheid gesoek vir hulle eie meninge. Die Biblisisme onderskat dus die betekenis van die konfessie.

As ons 'n sprong maak na die tyd van die Dordtse Sinode (1618-1619), blyk dit dat die Remonstrante met argwaan teenoor die konfessie besiel was. Dit sou volgens hulle in stryd wees met die uitsluitlike gesag van die Heilige Skrif, dit beroof die gewete van sy vryheid en sou dan die wasdom in die kennis teëhou. ${ }^{4}$ Die Remonstrante het die "referre ad Synodum" stelselmatig ontwyk. Hulle het by Dordt beweer dat hulle hul aan ,die substansie" van die leer hou. Kuyper maak in hierdie verband die opmerking dat die laksere opvatting ,der confessie juist door de divergeerende fractiën is voorgestaan".

Hierdie opvatting het in die vorige eeu kenmerkend na vore gekom by die Nederlandsche Hervormde Kerk, soos blyk uit die boek van Volger (De Leer der Nederlandsche Hervormde Kerk) en meer in besonder ook uit die standpunt van dr. J. J. van Toorenenbergen (sy werk: De Symbolische Schriften der Nederlandsche Hervormde Kerk waarin hy o.m. skrywe oor De Confessionele Praktijk in de Nederlandse Hervormde Kerk, 1561-1619). Dat Kuyper meer as voldoende rede gehad het om ernstig van Van Toorenenbergen te verskil en dat hy ook met hom swaarde gekruis het, word vir ons duidelik in Revisie der Revisie - Legende door dr. A. Kuyper, Amsterdam 1879.

In sy „Voorbericht” skrywe Van Toorenenbergen: „Al de stukken der leer in alles te handhaven, is zonder de vernieuwing van het actueel verband tusschen de gemeente en de voor haar nooit onverschillig of onnoodig te achten oorkonden van haar wezen als Hervormde Kerk ( $\mathrm{nl}$. die Nederl. Geloofsbelydenis en die Heid. Kategismus) eenvoudig onmogelijk" (bl. V). Dit is dus die standpunt dat ,al de stukken der Leer in alles" - soos vervat in die Drie Formuliere van Eenheid - onmoontlik gehandhaaf kan word. Van Toorenenbergen verklaar verder in die gemelde "Voorbericht" ,dat het der Gereformeerde Kerk steeds te doen is geweest om ,de Substantie der Leer' die zij belijdt te bewaren en niet om de handhaving van de oudheid der letter" (bl. V). Dit is duidelik dat volgens Van Toorenenbergen ,al de stukken der leer" en ,de substantie der leer" twee verskillende groothede is. Onder die term ,substantie" verstaan hy dan die "Credo" wat uit die Formuliere as die wesenlike inhoud te voorskyn tree tot 'n voortdurende en wettige evangeliese gebruik (bl. VI), die "fundamentele" in die leer in teëstelling met die minder gewigtige, die eintlike gesagvolle of kern in die Formuliere (bl. XXX), in teenstelling met die aksidentele (die tydelike, bykomstige bestanddele). Die belydenis het hy meer as ' $n$ dinamiese geloofsuiting van daardie tyd gesien as wat dit 'n statiese vaslegging van die waarheid is.

Van Toorenenbergen skrywe verder in sy „Voorbericht”: „Het 
is in het voetspoor der vaderen vórtgaan wanneer wij er rekening mede houden dat twee en eene halve eeuw lang iedere opzettelijke, officiële herziening van de Symbolische Schriften onzer Kerk is achterwegen gebleven. Daardoor is de betrekking der Kerk tot hare Formulieren noodwendig gewijzigd". Hierdie wysiging bestaan dan klaarblyklik daarin dat ,slegs de substantie der leer" nog aanvaarbaar is. Van Toorenenbergen verklaar „dat niet de geheele Symbolische Schrift als zoodanig de blijvende belijdenis der Kerk kan zijn..." Volgens Van Toorenenbergen besit die Canones van Dordt geen kerklike outoriteit nie: „Die merkwaardige leerregelen hebben als theologisch betoog niet slechts een tijdelijk, maar ook een schoolsch karakter. Daarom behooren zij tot de Symbolische apocrypha en moeten als een bijzonder deel van het corpus doctrinae worden aangemerkt" (bl. XXII). Die belydenisskrif het dus eintlik sy toepaslikheid en sy krag verloor en nutteloos geword. Die belydenis van die goddelike verkiesing en verwerping en die waarhede wat daarmee saamhang, word beskou as "simboliese apokriewe".

\section{Ondertekeningsformulier}

Wat hier na vore gebring is, lê in 'n lyn met die konfessionele standpunt van die Nederlandsche Herv. Kerk soos die Reglement van 1816 daaraan 'n beslag gegee het. Die Sinode van 1816 het 'n nuwe ondertekeningsformulier vir proponente aanvaar waarin belowe is om ,de leer welke overeenkomstig Gods heilig Woord in de aangenomen Formulieren van Enigheid is vervat, te goeder trouw aan te nemen en hartelijk te gelooven". Dit was 'n ingrypende verandering. Dit het die hoogs moontlike vryheid van leer toegelaat. "De leer welke overeenkomstig Gods heilig Woord” is, kon na willekeur as 'n quia- of quatenus-standpunt vertolk word. Volgens die quia-standpunt word die Belydenisskrifte onderteken met die belofte om dit te handhaaf omdat dit aanvaar word as in ooreenstemming met Gods Woord. Dit bind die ondertekenaars dus aan die handhawing van die suiwere leer. Volgens die quatenus-standpunt word die Belydenisskrifte slegs onderteken in so ver dit ooreenkom met Gods Woord. Die ondertekenaar kan dus self uitmaak wat in die Belydenisskrifte ooreenkom met God se Woord. Dit is 'n uiters subjektiewe maatstaf wat prakties uitloop op leervryheid. Hierby is ook, soos Bosch skrywe, die Dordtse Leerreëls „,stillekens weggelaten".

\section{Leervryheid}

In 1816 is dus die Dordtse K.O., die Dordtse ondertekeningsformulier en die Dordtse Leerreëls ter syde gestel waardeur die deure oopgegooi is vir ,alle vrijheid van leer". Die quatenus-standpunt het die Drie Formuliere van Eenheid net in ,wese en hoofsaak" aanvaar. Die konsekwensie is dat die belydenis op non-aktiwiteit gestel word; die weg tot onbeteuelde subjektivisme is oop - elkeen neem uit $\mathrm{Skr}^{\circ}$ en belydenis wat hom pas, met 'n verbygaan van die res. 
Die Herv. Kerk het hierdie weg steeds meer oopgemaak. In 1854 is die ondertekeningsformulier so gewysig dat volstaan kan word met die verklaring ,dat wij deszins en willens zijn den geest en cle hoofdzaak der leer, welke in de aangenamen formulieren van eenigheid der Nederlandsche Herv. Kerk begrepen is, getrouwelijk te handhaven". Dit het beteken dat die belydenis aanvaar word alleen vir so vér (quatenus) en nie omdat (quia) dit met die Skrif ooreenstem nie. By alle formele aanvaarding van die belydenis is tog die deur vir die grootste mate van willekeur geopen. Wie bepaal wat hoofsaak is en wat nie? Volgens welke maatstaf moet sodanige gradering geskied? Die onderskeiding van „gees en hoofsaak" is ook soms vervang met primêr-sekondêr, fundamenteel-nie-fundamenteel, inhoud-vorm. Een groot fout hier is dat daar op heel kwantitatiewe wyse oor die belydenis gedink word, as sou die belydenis uit 'n optelsom van 'n aantal waarhede bestaan.

In 1888 word dit nog meer rekbaar: Daar word dan belowe om „ooreenkomstig die beginsels en die karakter van die Nedl. Herv. Kerk hier te lande", die Evangelie van Jesus Christus te verkondig. Die drie Formuliere van Eenheid word dus nie eers genoem nie. Die willekeur, die losbandigheid in die leer het volle skeepsreg verkry.

\section{Die Gereformeerde Kerke}

Daar gaan in die Nederlandse Geref. Kerke wat uit die Afskeiding van 1834 en die Doleansie van 1886 voortgekom het, vandag stemme op wat sterk herinner aan wat ons so pas uit die kring van die Ned. Herv. Kerk in die vorige eeu verneem het.

Probleme rondom die belydenis is in 1962 opnuut aan die orde gestel met die verskyning van die boek van $d s$. H. Volten: Rondom het Belijden der Kerk, waarin, soos ds. J. Overduin dit opsom, ${ }^{5}$ Volten enersyds met die eenheidsvraag worstel en andersyds met die waarheidsvraag. Hy bekommer hom oor die verskeurdheid van die Herv. en Geref. Kerke in Nederland. Hy wil die weg aanwys vir die Geref. Kerke om uit hul isolement te tree; daarom vra hy meer ruimte vir die saamgaan met andere. Volten skets die betekenis van die belydenis as weergawe en konfessie van die leer van die Skrif en as antwoord op die leer van die Skrif. Hy beskryf die spanning tussen weergawe as vertolking van die Woord van God - dus, soos hy dit aandui - van die ewige en die absolute - en hy kwalifiseer die antwoord (konfessie) as feilbaar en as betreklike mensewoord. Waar is die grens? Wat is fundamenteel en wat aksidenteel? Hy pleit vir 'n onderskeiding tussen fundamentele en nie-fundamentele leerstukke. Hy beskou die woord ,reduksie" as een van die sleutelwoorde in die ekumeniese vraagstuk. Hy verdedig dit só: elke belydenis is eintlik 'n reduksie omdat die volle Bybelse getuien is nooit in ' $n$ belydenis omvat kan word nie. Reduksie - dit wil 'n prak. tiese toepassing van die onderskeiding tussen fundamentele en niefundamentele bestanddele wees. Volten sê die kerk is siek - sekere organe van die liggaam moet verwyder word. Dit moet egter in die 
reduksie gaan om 'n konsentrasie op die verlossing in Christus. Die reduksie of konsentrasie van die belydenis sal vir die Gereformeerde kerke beteken dat hulle bereid sal moet wees om die binding aan sommige dele van die drie Formuliere van Eenheid te laat val.

Tug

Volten sien voordele wat hieraan verbonde sal wees: die ware karakter van die tug sal gehandhaaf word - dit sal in 'n gekonsentreerde belydenis steeds gaan om die hart van die evangelie; nagmaalgemeenskap (oor kerkgrense heen) sal beter tot sy reg kom en die omvattende katolisiteit van die kerk sal meer beleef word. Die kerke moet, met 'n stuk van hul eie geskiedenis en van die eie belydenis op non-aktiwiteit, met mekaar 'n gesprek voer. Die solidariteitsgedagte van Bonhoeffer tree hier sterk na vore.

Die belydenis (aldus Volten) word Formuliere van eenheid genoem, maar die praktiese situasie is dat die belydenis uit mekaar geslaan het en dit nou nog altyd doen. Dit het die oorsaak van tallose splitsinge geword, veral toe die sonde van onverdraagsaamheid en liefdeloosheid ook nog 'n woord kom meespreek het. (,Daar zijn geen tranen genoeg, om deze waanzin der onderlinge verkettering ook maar enigzins bij benadering te beskreien" - Van Ruler oor die kerkskeuringe in Nederland).

Volten noem die verskillende weë waarlangs die kerke mekaar weer kan vind:

1. Die Biblisisme wat 'n streep trek deur die leerontwikkeling.

2. Deur die gereformeerde leer en die Gereformeerde kerk te verklaar tot die enigste ware leer en die enigste ware kerk (K. Schilder).

3. Die oplossing van A. Kuyper, nl. die van pluriformiteit. Hy gebruik die beeld van 'n boom wat één stam het, maar hom, namate hy groei, in vele takke uitsprei. So het die kerk ook oorspronklik net één stam gehad, maar dit was in die groeiproses van die kerk noodsaaklik dat dit in vele kerke moes uitspruit. Eén kerk het nooit die volle waarheid nie - daar is meer en minder suiwer kerke, ook die minder suiwer kerke lewer hulle bydrae. Dit is normaal dat die kerke naas mekaar moet bly staan. Of Volten Kuyper suiwer vertolk op hierdie punt, laat ons daarby.

4. Die vierde oplossing is dan dié van Volten, te wete die van die reduksie van die belydenis. Ons moet terugkeer tot die oudste konsilies (toe die kerk nog één was) en van daar uit dan in die hede tot 'n nuwe ekumeniese belydenis probeer kom. In die tussentyd moet die leerontwikkeling die pas markeer. Die tweede vorm is dan om 'n onderskeid te maak tussen fundamentele en nie-fundamentele waarhede (sentrale en periferiese waarhede) waarby alleen aan e.g. ' $n$ bindende karakter toegeken moet word. Hy het in 1962 in sy boek sterk daarvoor gepleit dat die Geref. Kerk by die Wêreldraad moet aansluit om saam te kan dink en mee te bid in die ekumeniese problematiek en daar self die seën van te ondervind. So nie, sê hy, sal die Geref. kerke verloop in sektarisme. ${ }^{6}$ 
Volten gee 'n opsomming van gebreke in die historiese belydenisskrifte. Van 'n letterlike binding aan die drie Formuliere van Eenheid kan in die kader van hierdie denke uiteraard geen sprake wees nie. Hulle is trouens syns insiens nie langer toereikend as vertolking van die boodskap van die kerk in die hede nie. Ook die kontrovers in die $19 \mathrm{e}$ eeu betreffende die vraag of die kerk aan die belydenis gebonde is quatenus (so vér) dit met die Heilige Skrif ooreenstem, of quia (omdat) benader hy op 'n nuwe manier. Hy lewer 'n pleidooi vir gestrengheid insake die fundamentele, en soepelheid en vryheid ten aansien van die nie-fundamentele in die kerklike belyde. Wat die skrywer voor die gees swewe is 'n modaliteitekerk waarin hulle wat tans deur verskille van ondergeskikte betekenis kerklik geskeie is, in een kerk kan saamlewe. Hy wil die grense dus wyer trek as die van die tans bestaande Gereformeerde Kerke.

As ons "quia" alleen sê (aldus Volten) beteken dit soveel as dat die Formuliere 'n feillose weergawe van die Skrif is. Dit sou beteken dat 'n gravamen uitgeslote is. Daarom moet ons sê quia én quatenus. Dan kan Skrif en belydenis nie gelyk gestel word nie. Hy beroep hom op Bavinck, Geref. Dogmatiek ${ }^{4}$ I, 63: „De Schrift is alleen norma en regula fidei et vitae; de belijdenis verdient alleen geloof, omdat en inzoover zij met de Schrift overeenkomt en blijft als feilbaar menschenwerk, revisibel en examinabel aan de Schrift".

\section{Plomp, Augustijn en Kuitert}

In die jongste verlede het nog meer stemme in die Gerefor. meerde Kerke in Nederland opgegaan wat die belydenis in die smeltkroes bring. Ons noem sekere uitlatings wat simptomaties is. Plomp skrywe dat die belydenis slegs 'n stel meninge van vrome vaders is. Die belydenis word dan op die vlak geplaas dat dit nouliks meer is as 'n persoonlike opinie. Augustijn stel die vraag of ons nog tuis voel in die klimaat van die belydenisskrifte. Per slot van rekening is dit net eerbiedwaardige dokumente wat die Bybel inperk en in die kader van 'n leersisteem pers. Die Bybel word blykbaar as weerloos beskou, en nou moet dit beskerm, omhein word deur die belydenis. God se Woord word aangevul deur of vervang met mensewoorde.

Augustijn sê dat die belydenis te 'n groot plek in die lewe van die kerke verkry het. Miskien is dit beter om te sê: ' $n$ verkeerde plek. Hy betoog dat sommige die pleit voer vir 'n nuwe belydenis waarin die kerk vandag kan uitspreek wat volgens sy insig die kern van ons belyde is. Die tydgebonde belydenisskrifte moet verdwyn. In nuwe woorde moet dieselfde geloof weergegee word. Ander sien die kern van die probleem in die ondertekeningsformulier. Volgens hulle blyk dit nie genoegsaam in hierdie formulier dat die Heilige Skrif in die kerk alleen reël en maatstaf vir geloof en lewe is nie. Verder moet dit blyk dat ons nie gebind is aan allerlei formuleringe wat in die belydenisskrifte te vinde is nie, maar dat dit gaan om die inhoud daarvan. Die vraag word gestel of die ou belydenisskrifte nog inderdaad ons geloof tot uitdrukking bring, al is dit dan maar in 
gees en in hoofsaak. Is hierdie belydenisskrifte wat reeds meer as vier eeue oud is, nie vandag al uitgedien soos 'n paar verslete skoene nie? Is die papier waarop dit geskrywe staan nie al 'n vergeelde stuk papier nie?

Augustijn sê daar kan nie beweer word dat die drie Formuliere van Eenheid tans die eendrag van die geloof tot uitdrukking bring nie. Dit is, verklaar hy, toe te skryf aan die ouderdom daarvan. In die 16e eeu was hulle op datum; hulle het egter hul tyd gehad. Die N.G.B. en Heid. Kategismus het in die $16 \mathrm{e}$ eeu weergegee wat wesenlik was vir die geloof; in die situasie waarin die kerk nou staan, kan weinig daarmee aangevang word. Die predikant wat vandag die Heid. Kategismus preek moet voortdurend uitlê, maar ook ander dinge sê, soms reëlreg teen die inhoud van die Heid. Kategismus ingaan. Daarby is die plek van hierdie belydenisskrifte in die Kerk vandag baie klein. Augustijn beskou dit as 'n gunstige teken.7

Kuitert spreek dieselfde taal as Augustijn. ${ }^{8}$ Vir hierdie „dokumente uit die gryse verlede" het hy weinig piëteit. Hy erken dat die uitholling en funksieverlies van die huidige kerklike instituut vir hom nie 'n oorsaak van bekommernis is nie. Hy sê dit sal miskien selfs baie nuttig wees as geen steen van die ou model op die ander sal bly staan nie. So sal die Gees weer kan waai waarheen Hy wil. Die Gereformeerde belydenis bestempel hy as 'n geloofsbelewing wat uit 'n tyd stam waarin ons nie meer lewe nie. Hy glo nie dat waarheid en eenheid bewaar kan word "deur die rigoreuse handhawing van die ou formuleringe nie". "Die Gees kry blykbaar eers ruimte wanneer die Gereformeerde belydeniskarakter van die kerk weggeneem is. Die konfessionele muur moet verdwyn. Hy verklaar dat as wat hy die ,oertemas" noem (dit is die kernpunte: o.a. maagdelike geboorte, versoening, opstanding, wederkoms van Christus) in ' $n$ belydenis vir hierdie tyd opgeneem moet word, daar probleme sal ontstaan, want dit is ' $n$ vraag wat hulle vandag nog vir ons beteken. Vir hom het die inhoud van die Christelike geloof in die kern van die saak, soos versoening, opstanding en so meer, vandag ' $n$ soveel ander betekenis as weleer. $H$. $N$. Ridderbos vra of hierdie heilswaarhede vandag so 'n uiteenlopende betekenis het dat dit onbegonne is om dit in 'n belydenis te probeer opneem? Die hartstog wat onmiskenbaar na vore kom is dat die kerk van die „ballas" van die verlede wat ook die werkinge van die Heilige Gees aan bande lê(!), bevry moet word, die kerk moet loskom van „tradisionele bindinge en vooroordele". Dit is duidelik dat Kuitert, Augustijn e.a. verder gaan op die pad van leervryheid, vrysinnigheid en modernisme as die Ned. Herv. Kerk. ${ }^{9}$

Hoe moet die situasie i.v.m. die binding van die belydenis gekonf ronteer word? Waarlangs loop die regte pad?

Ons wil daarop wys dat in die Geref. Kerken in Nederland van die kant van ' $n$ behoudende meerderheidsgroep sterk gereageer word teen die standpunt van Kuitert, Augustijn en hul geesverwante. Ridderbos beklemtoon dat die binding aan die belydenis ' $n$ wesenstrek van die kerk is. Wat die Geref. Kerk betref is in die verlede telkens 
weer daartéén gekies dat dit die gedaante van 'n „,hotelkerk" moet aanneem. Die Geref. Kerke het juis uit dié keuse voortgekom. En nou staan hulle weer voor dieselfde tweesprong. Nauta waarsku teen 'n oorhaastige poging om ,duidelikheid" te skep, solank die sake hulle nie duidelik uitwys nie. Hy vra of sake werklik so onduidelik is. Die groep wat aantygings teen die belydenis maak moet onthou dat die bewyslas by hulle berus. Hulle wil insigte op die kerk afdwing en verwag dat die kerk hóm daarvolgens moet gedra. Nou wil hulle die bewyslas omkeer. T.o.v. die diepste kernvrae is die belydenis oorduidelik: hoe kry ons deel aan die verlossing? Op welke wyse moet ons ons dankbaarheid toon in ons verhouding tot God en ons naaste, Soli Deo gloria? Ridderbos skrywe dat 'n kerk wat die teenstellinge wat hulle in hom voordoen intern nie kan oorwin nie, voor die keuse staan om uiteen te val of 'n "hotelkerk" te word waar elkeen 'n eie kamer het. Vandaar aan die een kant die veelvuldige afsplitsinge binne die gereformeerde Protestantisme, so anders as die toestand in die Ned. Hervormde Kerk waar die verskillende rigtinge tot 'n organisatoriese „coëxistentie" gekom het, maar waar daar van 'n egte kerklike gemeenskap tussen al hierdie groeperinge geen sprake is nie.

Daar is mense wat spanninge opwek. Hulle neem op hulleself 'n groot verantwoordelikheid. Die kerk het intussen die groot verantwoordelikheid om die spanninge op die regte kerklike manier op te vang. Die vraag is of die Geref. Kerke in Nederland sonder om 'n ,hotelkerk" te word, die eenheid sal kan bewaar, m.a.w. of die kerk met 'n goeie gewete met sy gereformeerde belydenis sy weg verder kan vind sonder om die afsplitsingsproses van die gereformeerde Protestantisme in Nederland weer nuwe voedsel te gee.

Ridderbos gee wyse raad wanneer hy waarsku dat verskille nie tot teenstellinge gemaak moet word nie. Die teenstellings word dan 'n oorsaak van skeuringe. Daar is verskille! Oor verskille moet ons egter mekaar die kerklike samelewing nie ontsê om ons dan elkeen in "ons eie hotelkamer" terug te trek nie. Ons moet die gevare sien, maar nie kortsigtige beslissings neem nie.

\section{Die regte pad}

As ons die regte pad probeer aandui, wil ons by Ridderbos se woorde aansluit dat ons nie in die groep van valse teenstellinge moet beland nie. Aan die een kant is daar die uiterste standpunt van die absoluutheid van die binding. Dan spreek die belydenis die finale woord. Aan die ander kant word vryheid in losbandigheid gesoek en word die binding van die belydenis relatief gemaak sonder perke. Die vraag is nou of daar nie 'n derde pad, 'n tertium is nie. As daar nie 'n derde moontlikheid is nie, dan is Rome reg. Die Roomse Kerk sê: jy mag nie afskei nię. Ons sê: jy mag, maar dan bly jy afskei (dit is fout) en kom jy tot die absoluutheid van jou kerk (vgl. die Vrijgemaaktes - K. Schilder). So ontmoet die twee uiterstes mekaar. Die tertium vind ons by Calvyn wat onderskei tussen relativiteit en 'n binding met voorbehoud: My kerk is die ware 
kerk, met 'n sekere voorbehoud (aliquam modo) m.a.w. met 'n „tensy" (vgl. die ondertekeningsformulier)..$^{10}$

Die standpunt t.o.v. die belydenis verskil dus grootliks van die van die Nederlandse Herv. Kerk. Die quia is ondubbelsinnige eis vir die ondertekenaar van die belydenis. Dit behels in hierdie sin die subjektiewe element, dat ek daarmee sê: omdat na my oortuiging, so vér my kennis nou strek - en dan bind ek my aan die kerklike weg. Die Nederlandse Hervormders opereer met 'n blanko-tjek ek bind my op die keper aan niks. Die quatenus beteken ten slotte geen binding hoegenaamd nie, willekeur, bandeloosheid. Die Gereformeerde sê: ek bind my ondubbelsinnig, maar nie in absolute sin nie - dan bind ek my aan die letter van die belydenis en nie net aan sy sg. ,gees en strekking" nie, want in lg. geval is daar eintlik geen binding nie - moreel miskien, maar nie juridies-kerkregtelik nie.

\section{Tekste}

Die jongsgehoue Sinode van die Nederlandse Geref. Kerke het, benewens heelwat ander beswaarskrifte, ook moes handel oor 'n beswaarskrif teen die Dordtse Leerreëls op die punt dat die tekste waarna verwys word nie met soveel woorde die verwerping leer nie. Dit het die kwessie na vore gebring of die belydenis op bepaalde punte hersien moet word. Die Sinode het, soos Ridderbos dit uitdruk, „gepersisteer" by die binding aan die drie Formuliere van Eenheid. Ondubbelsinnige binding bly gehandhaaf terwyl kragtens art. 49 K.O. deur deputate ad hoc die Heilige Skrif nou op daardie bepaalde punt geraadpleeg word. Dit raak egter nie die belydenis as belydenis nie - die bly gehandhaaf. Hier het ons die tertium: die binding word gehandhaaf, maar nie in absolute sin nie. Aan die ander kant word die belydenis ook in geen opsig gerelativeer nie, want daar moet eers bewys word voor die betrokke kerklike vergadering dat die belydenis op die punt in stryd met die Heilige Skrif is. Die deputate ad hoc het opdrag om die belydenis na te gaan ten einde vas te stel of daar faktore is wat die ondubbelsinnigheid van die Belydenisskrifte nog in die gedrang bring.

\section{Feilbaar}

Ons reken die konfessie ook tot die geskrifte van mense waarvan Art. VII N.G.B. spreek. Hoewel in die vorming van die belydenis die Heilige Gees bo alle twyfel werksaam is, mag ons egter nie daardie belydenisskrifte as onfeilbaar geïnspireerde geskrifte gaan beskou nie. H. Bavinck verklaar dat dit ,feilbaar menschenwerk, onvolkomene uitdrukking van wat de kerk uit de Schrift als Goddelijke waarheid in haar bewustzijn opgenomen heeft", is. Hy sien die plek van die belydenisskrifte nie naas, nog minder bo, maar diep onder die Heilige Skrif. Die absolute gesag van die Skrif as die Woord van God mag nie aangetas word nie. Alleen die Skrif is onfeilbaar, alleen die Skrif het absolute, onvoorwaardelike gesag. Vir die kerk het 
die Skrif alleen die laaste beslissende woord.

Die stryd van die Reformatore was nie om in hul verset teen die dwaalleer en gesagstruktuur van Rome revolusionêr met alle vastigheid en gesag weg te doen nie, maar dit was 'n stryd om reformatories die kerk te fundeer in sy ganse geworteldheid en lewensopenbaring in die Woord van die lewende God. Die „sola scriptura" moet die einde van alle teëspraak wees. Ons moet vashou aan die Reformatoriese "sola scriptura". Ons is nie en aan die Woord van God én aan die belydenis gebind nie. Die belydenis bind ons juis aan niks anders as aan die Woord van God nie, en verbied sélf elke ander binding (Art. 7 N.G.B.)." Ook die Dordtse Sinode wou almal bind ",non ulla scriptura humana, sed solum Dei verbo". So moet dit by ons steeds die geval wees. Die gesag van die belydenis is relatief, dit wil sê dit staan in 'n volstrek afhanklike relasie tot die Woord van God waardeur die kerk alleen kan bestaan. ${ }^{12}$ Die Heilige Skrif het dus primêre gesag in onderskeiding van die sekondêre gesag van die belydenis. Ons mag geen papier - of lewende pous duld nie. Juis die vashou aan die Heilige Skrif het gelei tot die opstel van belydenisskrifte, waarvan die toetsing steeds langs die ordelike, kerklike weg moet plaasvind - 'n toetsing deur die kerk waarin die skerp mes van die leertug altyd weer tot in die murg moet sny.

\section{Begrensing}

Die Sinode van La Rochelle het reeds in 1607 besluit dat die belydenis alleen gesag het in dit wat hy wil bely. Daarom kan dit in die een geval wees dat dit wat die belydenis wil bely, volkome duidelik na vore kom in die formulering en aangevoerde Skrifbewys, terwyl in die ander geval die gebesigde formulering juis nie daarin slaag om dit wat bely wil word, duidelik genoeg na vore te bring nie.

Die gelowige gehoorsaamheid aan die Woord en die voortdurende waaksaamheid om die Woord as Woord van God te hoor, sal daartoe kan bydra om te verhoed dat die Woord deur die belydenis ingeperk word. Calvyn sê dat die kerk maar net moet waak dat hy binne die grense van die Skrif bly (Inst. IV, 9). As dit nodig blyk, moet die dinamiet van die Skrif onder die formuleringe van die kerk geplaas word. Die dogma wat ons aanvaar moet ons telkens na die Skrif teruglei, en in die Skrif moet ons telkens die waarheid van die belydenis vind. So word die gevaar besweer van konfessionalisme - dat die belydenis bo of naas die Skrif gestel sal word, - of dat die Bybel 'n geslote boek word terwyl ons ons met die belydenis alleen tevrede stel. In die Skrif spreek God, in die dogma spreek die kerk. ${ }^{13}$ In die Bybel gee God sy gedagtes, in die dogma dink die kerk God se openbaring na. In die kerklike belydenis het God se Woord deur die feilbare denke en belyde van mense gegaan. Wie die twee gelyk wil skakel, oorskrei die grens wat ons spreke van die spreke van God skei.

Kuyper noem 'n aantal faktore waaruit die dogma ontstaan het: uit die stryd wat in die boesem van die kerk deur die antitese van 
die leuen gewek is; uit die geestelike proses wat die kerk ten gevolge van die stryd deurloop het; uit die amp wat as sodanig tot die noem van ' $n$ beslissing opgeroep is; uit die leiding van die Heilige Gees in gehoorsaamheid aan die Woord van God.14

\section{Die weg van gravamen}

Die Gereformeerdes het, anders as Rome, die weg geopen vir die teoloog om sy eie gevoele teenoor die belydenis te verdedig. $\mathrm{Hy}$ mag dit egter nie publiek doen nie, maar op die betrokke kerklike vergadering mag en moet hy sy besware, indien so iets hom voordoen, bring. Hierdie reg om gravamen in te dien is van betekenis vir die kerk self en vir die persoonlike vryheid. Die vryheid van oortuiging word dus deur die Geref. Kerke gehandhaaf. Die kerk durf die eerlike konkurrensie met die leuen, met ongeloof en wangeloof aan, in die oortuiging dat die waarheid sal oorwin. Maar niemand kan en mag van die kerk verwag dat hy die verkondigers van dwalinge en ongeloofslering vry binne sy erf sal laat werk nie. Daar moet gewaak word vir die eer van God, die heil van die gelowiges en die suiwerheid van die gemeente. 'n Kerk wat sy belydenis nie handhaaf, en nie na en uit die belydenis lewe nie, gee die skape van Jesus se kudde geen regte voeding en leiding nie, laat hulle afdwaal op verkeerde paaie en loop self gevaar vir versterwing. Die belydenis het nog steeds gedien om die ketters aan hul dwaling te ontdek, die leraars onder mekaar eendragtig te hou, skeuring te vermy en die suiwere leer aan die nageslag oor te lewer. Willekeur in die leer verdeel, vastheid in die leer bewerk eenheid en bou die kerk op.

I.v.m. bedenkinge wat teen die konfessie na vore mag kom, word die vraag in die Nederlandse Geref. Kerke gestel of die weg van gravamen die enigste weg is. Daar word gespreek van ,intrakonfessionele verskille". Plomp se standpunt is dat 'n gravamen nie mag gaan oor allerlei swakhede en gebreke wat a.g.v. die menslike faktor eie is aan die belydenis of betrekking het op die beperkthede wat saamhang met die historiese situasie waarin die belydenis ontstaan het nie. Hy sê dit moet gaan teen die wesenlike bedoeling van 'n belydenisskrif of belydenisuitspraak, teen die doctrina (leer, prediking) wat die belydenis beoog om te beveilig. Berkouwer meen dat as 'n mens met jou beswaar binne die ,diepste intenties" van die belydenis bly, dit nie noodsaaklik is om gravamen in te dien en dus revisie te vra nie..$^{15}$ Berkouwer verklaar self dat die gevaar van ,subjektieve willekeur en van het latent worden van de woorden van de belijdenis" by hierdie standpunt nie denkbeeldig is nie. ${ }^{16}$

In elk geval lê dit o.i. op die weg van die bevoegde kerklike vergadering om uit te mak of verskil by ' $n$ ampsdraer met die belydenis in sy letterlike binding intrakonfessioneel is of nie. Dit mag nie aan die willekeur van individue oorgelaat word nie. Die ondertekeningsformulier vereis dat die koninklike weg bewandel moet word wanneer daar ,enige bedenkings of ander gevoele" na vore kom, om naamlik ,dit nie, hetsy openlik of in die geheim 
in die prediking of in geskrif, bekend te maak, te leer of te verdedig nie, maar dat ons dit eers aan die kerkraad, klassis of sinode sal openbaar..."

\section{Binding}

Die gesag van die belydenis is inherent aan sy wese as belydenis (Hebr. $4: 14 ; 6: 2 ; 10: 23 ; 13: 9$ ). Die belydenis dat Jesus Christus in die vlees gekom het ( 1 Joh. $4: 2$ e.v.), is die grondslag waarop onderskei word tussen die gees van die waarheid en die gees van dwaling. Bouma verstaan „die leer" waarna in Titus 1 : 9 verwys word as die ,door de kerk vasgestelde leer".

Die Reformasie het die kerklike gesag binne die Skriftuurlike grense teruggebring. Bly die kerk ook met sy dogma binne hierdie begrensing, kan ons wel deeglik van gesagsuitoefening spreek wat Skriftuurlik verantwoord is. Die kerk het van Christus leer- en tugmag ontvang. Ons verwys slegs na Matt. 16 : 18 e.v. En 'n gesag wat nie bind nie, is geen gesag nie. Die kerk gee toe dat hy hom kan vergis - dit mag hom ook uit God se Woord op 'n ordelike wyse aangetoon word; kan 'n mens dit nie doen nie, moet jy jou aan die kerklike uitspraak hou. Die moontlikheid dat die enkele gelowige hom vergis, is egter duisend, tienduisend en nog meer male groter as dat 'n kerk wat angsvallig in gebondenheid aan die Skrif wil lewe, hom sal vergis. Deur instemming met sy dogmata te eis, dring die kerk tot deurlewing, spoor dit aan tot persoonlike ondersoek en rekenskap. Op grond daarvan dat die dogma volkome afhanklik bly van die Skrif, daaruit geput is onder die leiding van die Heilige Gees, in samespanning van die gelowiges van alle eeue, kan die kerk met krag spreek en sy belydenis met gesag voordra. Deur vele gevare en dwalinge heen het die kerk in sy dogma's 'n duidelike pad aangewys.

As ' $n$ mens aanneem dat ons belydenisskrifte in alles met die Woord van God ooreenstem, dan het jy geen beswaar teen die sekondêre binding van die kerke daaraan as akkoord van kerklike gemeenskap en as band van kerklike eenheid nie. Trek ek die belydenisskrifte egter in twyfel, dan het ek wel beswaar teen sodanige sekondêre binding. ${ }^{17}$

Ons moet waak dat die belydenis sy outoriteit nie ontneem sal word as akkoord van kerklike gemeenskap nie. Dit is die uitdrukking van wat die kerk omtrent bepaalde punte as waarheid glo. Vir die goeie gang en die opbou van die kerklike lewe is dit 'n onmisbare vereiste dat die eenheid, die suiwerheid in leer, diens en tug in die belydenis tot uitdrukking sal kom. Daarmee moet die lede van die kerk hul instemming betuig en daaraan moet hulle hul onderwerp.

\section{Antwoord}

Die konfessie is gebore uit die lewensbehoefte van die geloof om hom uit te spreek. In die belyde blyk dat die waarheid ons hart gegryp het. As God spreek, wil die geloof antwoord. Wanneer ons 
ons verdiep in die Skrif en in die stem van die kerk wat oor eeue heen in die belydenis tot ons kom, dan word ons getref deur die getroue, gehoorsame, diep religieuse belyde van die kerk. Hierdie belydenis moet leef in die kerk, dit mag nie 'n antikwiteit word nie. Hy wat die taal van die belydenis, die inhoud sy eie maak, verkry as wins die stralende uitsig van die geloof met die kerk van die eeue. Net 'n karakterlose kerk bêre sy belydenis in 'n brandkas.

Die krag van die belydenis is in sy vastigheid geleë. Omdat dit die geval is, koester ons ernstige bedenkinge teen die oorbeklem. toning van die dinamiese, aktualistiese, die onvaste by die dialektiese teoloë. Karl Barth se grondgedagtes oor die Heilige Skrif lê ook ten grondslag aan sy siening van die belydenis. Om tot die dogma te kom is volgens Van Niftrik 'n „unendliche Aufgabe”. Vergelyk wat Barth sê van die openbaring van God wat is soos die water van Betesda. Die belydenis mag nie staties wees nie; dit vind hulle star, onbeweeglik. Daar kan dan ook nie sprake van binding wees nie.

\section{Eggo}

Die kerk begin nie by ons nie. Ons is oortuig dat ons vaders die leer só onder woorde gebring het, dat die weergawe in alles met die Woord van God ooreenstem. As die belydenis die suiwer eggo van die Woord van God is - en dit aanvaar ons onomwonde - dan staan dit bo die tyd en bly dit steeds aktueel. Soos in die Skrif, val ook in die belydenis die swaar aksent nie op die dinamiese nie, maar op die statiese, op sy vastheid en duur. By die aktualistiese openbaringsbegrip van Barth, van Niftrik e.a. pas 'n dinamiese opvatting van die belydenis soos hierbo gemeld. Die Skrif spreek egter telkens van die gesonde leer, die toevertroude pand, die allerheiligste geloof wat oorgelewer is en daarom ook van die goeie, onwankelbare belydenis waaraan die gemeente moet vashou. Die kerk moet pilaar en grondslag van die waarheid wees.

Die Geref. Kerk het hom in die $17 \mathrm{e}$ eeu met krag en klem verset teen die revisionisme (die voortdurende te moet hersien) van die Remonstrante, terwyl hulle wettig ingediende gravamina teen bepaalde uitsprake van die belydenis ernstig wou bly oorweeg en aan die Skrif toets. Die kerk mag hom nie in voortdurende onrus laat beland nie. Die kontinuïteit van die belydenis, sy vastheid, sy duursaamheid spreek ons baie sterk aan. Dit is die belyde van die kerk van die eeue. Die band met die verlede mag nie verbreek, die leiding van God se Gees nie geloën word nie. Die handhawing van die ou waarheid wat uit die suiwere bron van die Skrif gevloei het, is die reg van die gemeente en die plig en roeping van die kerk.

\section{Het alles so verander?}

Ons moet ons goed daaroor besin of daar in die grond van die saak selfs na vier eeue werklik soveel verander het en of die vrae in die kern nie maar dieselfde bly nie, terwyl die antwoord van God daarop in sy Woord ewemin verander. Die bo-tydelike en hoogs- 
aktuele karakter van die ou Formuliere midde in ons tyd, in die kerk en in die wêreld van die hede moet ons meer laat uitstraal.

Dit is lankal tyd dat ons opnuut die harnas aantrek van die dogma's waaraan die geur van brandstapels kleef. Kuyper het reeds gekla dat daar so min goed van die belydenis gepraat word en dat die konfessie (destyds in die kringe van die Ned. Herv. Kerk) voortdurend in 'n staat van beskuldiging gehou is. En, sê hy, die belydenis is nie 'n stuk armoede van die kerk nie, dit behoort tot sy grootste rykdomme. Ons leef in 'n tyd van velerlei dwalinge en groot verwarring op geestelike gebied. Naas warmte van hart is ook 'n klare onderskeidingsvermoë nodig om die geeste te kan beproef of hulle uit God is.

\section{Woelsiek}

Dit is ' $n$ hoogsverontrustende verskynsel dat ook in gereformeerde kringe 'n belydenisphobie duidelik aan die lig tree. Daar word vroeg en laat argwaan teen die belydenis aangeblaas. Kuyper sê tereg dat as die kerk ophou om belydeniskerk te wees, hy draer van 'n wisselende mening is en dit maak dan dat „woelsieke geeste" vrye spel kry om allerlei kwessies op te werk en telkens alle reeds vroeër afgedane ketterye te hernuwe. Dit laat ook die vaste lyne van die kerkregering verdof. Dit sit dus 'n proses van deformasie oor die hele linie aan die gang.

\section{Die eietydse}

Polman skrywe dat die kerk aan wie die woorde van God toevertrou is, en aan wie die leiding van die Gees toegesê is, as pilaar en grondslag van die waarheid moet waak vir die ongerepte bewaring van die evangelie van Christus, soos dit in die tyd van die Reformasie verstaan en bely is, en dat die kerk as moeder van die gelowiges ruimte moet laat vir die eietydse vertaling daarvan. Die Gereformeerdes mag in die woorde van a'Lasco die ontwikkeling van die volgende eeue nie afsny by die meerdere lig, wat dit God mag behaag om te ontsteek nie. Ursinus het gesê: „dit wat verbetering nodig het, moet verbeter word". Dit moet volgens Voetius geskied „,indien iets dubbelsinnigs geskrywe is, indien iets aan die belydenis moet toegevoeg word, of ook indien nuwe ketterye opgeduik het" (Pol. Eccl. III, 21). Revisie is steeds moontlik, maar hierdie revisie is alleen dan profytlik as die kerk self op 'n hoë geestelike standpunt staan, en na deeglike studie en sorgvuldige voorbereiding, met vashou van die beginsels, in staat is om meer juis en skerp uit die Skrif die uitdrukking van sy geloof vas te stel (Polman: Chr. Enc., I, bl. 552).

Prof. S. du Toit skrywe: „Onder biddende opsien tot God, en met inagneming van sowel die Scylla van verstarring as die Charybdis van verwarring, kan die kerk van Christus in hierdie apokaliptiese tyd 'n helder geluid laat hoor, kontinu met die kerk van alle eeue, maar ook aktueel vir die tyd waarin ons lewe" Althaus waarsku 
die kerk om die belydenis nie tot 'n Chinese muur te maak, waaragter die kerk hom terugtrek en hom van die vrae van die hede distansieer nie.

\section{Die beeld van die eik}

Ook in hierdie opsig moet die kerk wees soos die eikeboom. Die wortels van hierdie boom is eeue reeds diep en stewig in die bodem vervleg. Met die jare word hierdie verankerdheid selfs al stewiger. Ondertussen neem die stam en takke steeds in omvang toe. Elke lentetyd is daar nuwe spruite en aanskou ons die groen kleed. Maar die boom strewe ook na die toekoms. Hy werk hom al hoër op. Die jong takkies voorspel dat die kruin na verloop van tyd groter hoogtes gaan bereik en dat die kroon nog voller en koninkliker gaan wees. Die ou, beproefde fondamente messel ons nie oor nie, maar ons moet eeu in, eeu uit voortbou, sodat, as dit God mag behaag, die wens van die Sinode van Dordrecht (1618-1619) in volle vervulling mag gaan ,dat men deze Gereformeerde leer onverminkt en ongeschonden zal overleveren aan de nakomelingschap tot op de wederkomst des Heeren".

Prof. dr. P. J. Coetzee.

(Gelewer te Saamtrek, o.l.v. G.T.V.Johannesburg, Florida, Mei 1970)

1 H. Bavinck: Geref. Dogmatiek, I, p. 7.

2 G. C. Berkouwer: Conflict met Rome, p. 43.

3 Christelijke Encyclopedie, 2, p. 448.

4 Die geskiedenis van die Geref. Kerke in Nederland bewys dat dit die Remonstrante was wat aan die einde van die $16 \mathrm{e}$ en die begin van die 17e eeu alles in hul vermoë gedoen het om die belydenis uit die kerk as Formulier van Eenheid en akkoord van kerklike gemeenskap geweer te kry. „De Remonstranten beschuldigden de Gereformeerden... dat zij door de belijdenis aan het gezag, de genoegzaamheid en de volmaaktheid der Heilige Schrift te kort deden. Maar de Gereformeerden, schoon in deze bedeeling der kerk eene belijdenis noodzakelijk achtende, om het Woord Gods te verklaren, de ketterijen te weren en de eenigheid des geloofs te onderhouden, bestreden zoo sterk mogenlijk, dat de belijdenis ook maar eenig gezag zou hebben naast de Schrift" (Bav. Dogma, I, 63).

5 Belijden en Beleven, 16 Aug. 1962.

6 Voorheen (1949, Den Haag) het die Sinode van die Geref. Kerk in Nederland met groot meerderheid teen die Wereldraad besluit. Nou (1970 Lunteren) is die voorstel tot aansluiting sonder slag of stoot aanvaar. Ridderbos sê die Wêreldraad „is inderdaad 'n raad van kerken gebleken", géen superkerk, ook geen smeltoond om elke deelnemende kerk so spoedig moontlik sy identiteit te laat verloor nie. Die W.R. ontwikkel nie in ' $n$ eenheidskerk nie. Dit het 'n belangrike ontmoetingspunt geword. Aan die een kant moet die kerk sy eie identiteit bewaar, aan die ander kant moet daar na'wyer gemeenskap gesoek word. Die ontmoeting met ander 
kerke wat 'n ander stempel dra, mag nie ontwyk word nie. Die vraag is net hoe dit moet gebeur en wat daarby as ideaal gestel moet word. Aldus Ridderbos. Die Nederlandse kerke soek dus toenadering - daaruit is die besluit gebore om by die W.R. aan te sluit. Daar word ook 'n brug gebou na die Ned. Herv. Kerk met wie die Geref. Kerke, soos dit lyk, eventueel gaan verenig. Die Sinode van Lunteren het egter pertinent binding aan die belydenis bevestig - nou is dit vir die W.R. en vir die Ned. Herv. Kerk om uit te mak in hoeverre hulle vir assosiasies met die Nederlandse Geref. Kerke wat hul identiteit wil handhaaf, kans sien. Die Nederlandse Geref. Kerke sè dus eintlik vir die W.R. en die Ned. Herv. Kerk: „Ons wil ons met julle assosieer, maar julle moet ons neem soos ons is - ons gaan ons identiteit nie verloën nie".

7 Sien: Dr. C. Augustijn: Kerk en Belijdenis, veral hoofstuk X, Wat nu? In hierdie verband herinner ons aan die woorde van Hoedemaker dat die Nederlandse Geref. Kerke eers gely het aan hipertrofie (oorvoeding) van die belydenis; dit, sê hierdie Ned. Hervormer, het in 1834 en 1886 geblyk (Afscheiding en Doleansie), dic Assen-besluit in die twintiger jare van hierdic eeu en die kerklike stryd wat lei tot die totstandkoming van die Vrijgemaakte Geref. Kerk in die veertigerjare. Nou is daar weer gans te veel soepelheid.

8 Geref. Weekblad, 13 Maart 1970, 20 Maart 1970.

9 Daar word argwaan, wantroue teen die belydenis gestook. Die vraag is wanneer die kerk moet ingryp. Na ons gevoel kan dit te lank duur. Die situasie is egter nie so eenvoudig nie. Tydens die Reformasie was daar konkrete punte. Vandag omsingel dwaalleer die kerk: hier steek 'n saak die kop uit - dan weer daar. Dit is 'n toestand van omsingeling. Dit is soos met die koue oorlog - jy het nie 'n linie voor jou nie, en dit is moeilik om die vyand in sy nes by te kom. Die kerk mag ook nie oorhaastig handel en daardeur bevorder wat hy juis wil besweer nie. Dit kan onnodig verwarring skep as hier 'n groepie Augustijnmense en daar 'n groepie Kuitertmense aangepak word. Ridderbos skrywe egter dat daar nou 'n punt bereik is dat die betrokkenes op 'n tweesprong staan.

10 A. D. R. Polman: Onze N.G.B., I, bl. 65/66; vgl. ook A. Kuyper: Encyclopaedie der Heilige Godgeleerdheid, III, bl. 373: „dat geen dogma ooit de adaequate uitdrukking van de waarheid is, dat uit dien hoofde geen dogma ooit anders dan relatieve zekerheid biedt, dat dienvolgens de dogmatische ontwikkeling nog steeds voortgaat, en dat het, met het oog hierop, van geen gering gewicht is te achten, ook de divergeerende en convergeerende neigingen der onderscheidene symbolen in hun onderlinge verband, in rekening te brengen. Vgl. ook S. du Toit: Bybel, Skepping en Evolusie, bl. 54.

11 Die Skrif alleen is onvoorwaardelik - bindend. Die belydenis is geen norma normans (normerende norm) nie, maar hoogstens norma normata (genormeerde norm). Dit is nie 'n reël wat die norma in homself het nie, maar 'n afgeleide reèl van die geloof. Dit is feilbare mensewerk, onvolkome uitdrukking van wat die Kerk uit die Skrif as goddelike waarheid in sy bewussyn opgeneem het. Sodra die belydenis van sy gerigtheid op die Skrif losgemaak word, het dit outonoom geword, maar daarmee is dan ook sy gesag ingeboet. Sien H. Bavinck: Dogm. IV, bl. 401. 
12 G. C. Berkouwer: Conflict met Rome, p. 22.

13 Dogma der Kerk, p. 11.

14 A. Kuyper: Encyclopaedie der Heilige Godgeleerdheid, III, p. 359.

15 G. C. Berkouwer: Geref. Theol. Tijdschrift, Febr. '63, bl, 19 e.v.

16 G. F. Meuleman (Oecumene en Belijdenis - Bezinning, Jrg. 15, 1960, nr. 3) spreek i.v.m. die belydenis van „sentrum en periferie”. „De periferie is niet onbelangrijk, dus niet onwezenlijk. Immers ze staat in samehang met het centrum. Maar tog heeft niet ieder onderdeel van de belijdenis voor de gelowige, voor de kerk dezelfde betekenis". Die ander standpunt is dié van letterlike binding (Berkouwer verkies om van „textualistiese opvatting" te spreek). Berkouwer sê ons het met 'n onaanvaarbare dilemma te doen as ons wil kies tussen hierdie twee standpunte: daar kan nie sonder meer die een of die ander weg gekies word nie. Daar is die gevaar dat die belydenisskrifte met 'n formalistiese letterlike binding vir ons 'n onfeilbare kanon kan word wat 'n bedoeling en intensie van sy eie het, los van die Woord van God. Die vraag is egter of ons nie 'n „ontmitologisering" van dic belydenis kry sodra van die letterlike binding wegbeweeg word nic. Die gedagte dat net vasgehou moet word aan dic "hoofstrekking" van die belydenis is 'n gevaarlike vryheid.

Kuyper skrywe: Dic vraag is of in die kerklike instituut deur aanvaarding van die konfessic bedoel word "adhaesie" aan sy substansic of aan sy hele inhoud. Kuyper antwoord bevestigend in die laaste sin.

17 Ds. J. V. Coetzee: Neo-Calvinisme, bl. 52. 